\title{
Soil nematode community characteristics around the Gangue hill of Fushun West Open-pit mine
}

\author{
W. D. ZHANG, Y. XIAO, X. F. WANG, Y. LV
}

Department of Environmental Science, College of Life Science, Liaoning Normal University, Dalian 116029, China, E-mail: zhangweidong64@yahoo.com.cn

\begin{abstract}
Summary
Diversity and nematode abundance were investigated in soils collected around the Gangue hill of Fushun West open-pit mine to evaluate soil pollution, due to heavy metals contents, using nematodes as bioindicators. Nematodes were collected from soil samples using elutriate-sievingflotation and centrifugation methods. The species richness and ecological indices were analyzed. On the base of chemical and nematological analysis, the results indicated that the area around the Gangue hill of Fushun West Openpit mine was polluted by heavy metal, but the degree of pollution was not very serious. According to the results obtained from single-factor analysis, cadmium soil content was ten times higher than the background; 29 genera of nematodes were identified and Acrobeloides, Cervidellus and Mesorhabtidis were the dominant genera in almost all sampling sites. The dominant genera were different as the distances to the Gangue hill changed. In particular, in the investigated areas bacterivores and plant-parasites nematodes were more diffuse than fungivores and omnivorepredators. Copper soil content was significantly correlated with plant parasitic trophic group and with total number of nematodes, thus suggesting that nematode communities studies are important scientific basis for understanding the healthy development of soil ecosystem.
\end{abstract}

Keywords: soil nematode community; heavy metals; soil contamination; soil ecosystem; ecological indices

\section{Introduction}

Accumulation of gangue as well as its spontaneous combustion can cause severe pollution and adverse effects on the surrounding environment in the mining area. The emissions during the spontaneous combustion such as carbon and sulfur dioxide, nitrogen oxides, hydrogen sulfide and various dusts are seriously harmful to atmospheric and water environments. Gangue leachates deriving by rain contain a lot of harmful heavy metals and acidic water which pollute both surface water and groundwater. In addition, these materials cause air and soil pollution, and they seriously undermine the mining area and the surrounding ecological environment.

Soil nematodes are important functional components in soil-ecosystem (Freckman, 1988; Hu et al., 1999) and they play important roles in the process of organic matter decomposition (Ingham et al., 1985; Hu et al., 1999) and mineralization of plant nutrients and their cycles. Because of soil nematofauna is rich in many categories and nematode genera, many species can survive in extreme conditions (Powers et al., 1995; Freckman \& Virginia, 1997), moreover soil nematodes have a short reproduction time and they are highly responsive to habitat changes. Researches about them not only reveal structure of the soil ecosystem, but also provide unique information about soil ecological processes (Ritz \& Trudgill, 1999). Therefore, nematodes can be widely used as indicator organisms useful to assess the degree of soil disturbance (Bongers, 1990; Wasilewska, 1997; Yeates et al., 1999a, 1999b). Nematodes have potential ability to monitor the status and the processes of the soil-ecosystem (Ritz \& Trudgill, 1999) and they can be used as informative factors in different ecosystems (Wardle et al., 1995; Freckman \& Virginia, 1997; Yeates et al., 1999b). Composition of soil nematode communities and the changes of their diversity can also instruct disturbance and restore level of soil ecosystem (Pate et al., 2000; Panesar et al., 2001; Li et al., 2002; Háněl, 2003; Čerevková \& Renčo, 2009). Since the 1990s, many countries focused their attention on researches about changes of soil nematode communities in different environmental conditions and management (Sohlenius et al., 1987; Freckman \& Ettema, 1993; Fu et al., 2000; Renčo, 2003, 2004; Ferris et al., 2004; Wasilewska, 2006; Zolda \& Háněl, 2007). Some relevant researches were reported during the last two decades in China (Wang et al., 1992; 
Hu et al., 1993; Li et al., 2002; Liang et al., 2005; Wu et al., 2005; Zhang et al., 2007a; Hu \& Qi, 2010).

To provide a theoretical foundation for the soil nematodes, we used the area around Gangue hill as an experimental site and we focused our attention on number of soil nematode communities, community composition, diversity, trends of changes, heavy metal pollution gradients in different sites and soil environmental quality within nematodes can survival.

Studies on soil nematode species diversity and their composition, such as trophic group diversity, life history and functional diversities, distribution and various eco-indices, are important elements to provide scientific bases for promoting the healthy development of soil-ecosystem, to offer references for further remedy of soil pollution and to supply an effective method to evaluate condition and level of heavy metal polluted soil in soil-zoology field.

Fushun coalfield is located in northeast of Liaoning province, and it is the largest mining area in Liaoning. West Open-pit mine is located in the most western part of Fushun coalfield. In particular, the subsidiary open-pit mine named Old City was derived by Fushun Open-pit mine in 1914. In addition, other two open-pit mines in 1917 and 1927 were also derived. So the three open-pit mines were combined and they formed West Open-pit mine that is one of largest open-pit mines in the world and the largest in China (6.6 kilometers long, 2 kilometers wide, and 290 meters deep). Coal and pungernite are the main productions of West Open-pit mine.

West Dumping Site is the biggest dumping site of West Open-pit mine, it is located in west of West Open-pit mine and $2.5 \mathrm{~km}$ away from it. There are steel and aluminum factories and mines at the back of it. Overall, the southern part of West Dumping Site is higher than the northern part, so the direction of catchment is from south to north. It has been used since 1928, so the rubbish materials have been accumulated for more than 80 years. It covers about 13.4 square kilometers and the main contents derive from openpit mine, such as oil-shale lean or spent shale. The West Dumping Site has created serious environmental problems and great harm to local people.

Therefore, with the aim to evaluate soil pollution around Gangue hill of Fushun West Open-pit mine a soil nematode survey was carried out collecting soil samples for nematode extraction, their microscope observation and to evaluate the nematode communities changes according to heavy metal pollution gradient.

\section{Material and Methods}

\section{Soil sampling}

Soil samples, each consisting of fifteen cores $(2.5 \mathrm{~cm}$ diameter $\times 20 \mathrm{~cm}$ deep), were collected from the area around Tian Tun and Qing Tai Zi where a gangue hill belongs to West Dumping Site situates in. Li Shi Zhai was considered as a reference point for six sampling sites which were perpendicular to gangue hill. There were three replications for each sampling site, samples were collected every 200 $\mathrm{m}$ by using three point hybrid-like method, the size of sampling grid was $40 \mathrm{~m} \times 80 \mathrm{~m}$. Sampling depth was about $20 \mathrm{~cm}$ because of at this soil depth nematodes are more abundant than other soil depths (Renčo et al., 2010). For each soil sample, topsoil was removed and then approximately $500 \mathrm{~g}$ soil were collected and stored into plastic bags. The soil samples were labeled and in the laboratory they were stored in a refrigerator at $4{ }^{\circ} \mathrm{C}$ until their use for chemical analysis and nematode extraction.

The soil was thoroughly mixed before to extract free-living soil nematodes. Nematodes were separated by using elutriate-sieving-flotation and centrifugation method (Barker et al., 1985). The recovered nematodes were counted through microscopic observation and their total number was expressed per $100 \mathrm{~g}$ dry weight soil. One hundred randomly selected specimens per sample were identified to genus level, according to Siddiqi and Bongers Nematodes Category Map. The classification of nematodes was refered to bacterial feeders $(\mathrm{BF})$; fungal feeders $(\mathrm{FF})$; plant-parasites (PP) and omnivore-predators (OP) based on known feeding habitats or stoma and esophageal morphology (Yeates et al., 1993; Yardim \& Edwards, 1998; Liang et al., 2001).

Soil samples were air-dried, stones were removed, soil was weighted and aggregated particles crushed. Soil was sieved on $2 \mathrm{~mm}$ pore sieve to obtain fine earth for chemical analysis. For each sample a representative amount of $0.5 \mathrm{~g}$ soil was digested by using $\mathrm{HNO}_{3}-\mathrm{HClO}_{3}(3: 1, \mathrm{v} / \mathrm{v})$ to assess total heavy metal content. Soil samples were handled in the atomic absorption spectrophotometer to determine the content of $\mathrm{Cd}, \mathrm{Cu}, \mathrm{Ni}, \mathrm{Pb}$, and $\mathrm{Zn}$.

\section{Nematode ecological and diversity indices}

The characteristics of the nematode communities were described by the following approaches and formulae: Ma-

Table 1. Heavy metal contents of soil collected around the Gangue hill of Fushun West Open-pit mine ( $\mathrm{mg} \cdot \mathrm{kg}^{-1}$ soil) in Liaoning Province (China)

\begin{tabular}{ccccccc}
\hline $\begin{array}{c}\text { Heavy } \\
\text { metals/Sites }\end{array}$ & 1 & 2 & 3 & 4 & 5 & 6 \\
\hline $\mathrm{Cu}$ & $75.37^{*} \mathrm{~b}^{* *}$ & $50.95 \mathrm{e}$ & $84.22 \mathrm{a}$ & $67.33 \mathrm{c}$ & $37.59 \mathrm{f}$ & $56.55 \mathrm{~d}$ \\
$\mathrm{Zn}$ & $72.43 \mathrm{~b}$ & $68.38 \mathrm{~b}$ & $78.65 \mathrm{a}$ & $70.56 \mathrm{~b}$ & $85.74 \mathrm{a}$ & $76.06 \mathrm{ab}$ \\
$\mathrm{Pb}$ & $45.44 \mathrm{a}$ & $40.07 \mathrm{ab}$ & $48.55 \mathrm{a}$ & $35.67 \mathrm{~b}$ & $37.05 \mathrm{~b}$ & $36.6 \mathrm{~b}$ \\
$\mathrm{Cd}$ & $2.48 \mathrm{a}$ & $2.58 \mathrm{a}$ & $2.75 \mathrm{a}$ & $2.03 \mathrm{ab}$ & $1.64 \mathrm{~b}$ & $2.04 \mathrm{ab}$ \\
$\mathrm{Ni}$ & $156.34 \mathrm{a}$ & $71.34 \mathrm{~b}$ & $69.9 \mathrm{~b}$ & $58.16 \mathrm{bc}$ & $53.74 \mathrm{c}$ & $55.62 \mathrm{c}$ \\
*Average of three replicates; ** Data flanked in each row by the same letters are not significantly different according to LSD's Test $(\mathrm{P}=0.05)$.
\end{tabular}


Table 2. Trophic groups and proportion of nematode genera (\%) in the different sampling sites around the Gangue hill of Fushun West Open-pit mine (Liaoning Province - China)

\begin{tabular}{|c|c|c|c|c|c|c|}
\hline Genus/Sites & 1 & 2 & 3 & 4 & 5 & 6 \\
\hline $\mathbf{B F}^{*}$ & 43.1 & 34.1 & 37.0 & 38.7 & 43.8 & 63.5 \\
\hline Acrobeles & 2.6 & 0.0 & 0.0 & 0.0 & 0.0 & 1.2 \\
\hline Acrobeloides & 7.8 & 12.9 & 8.6 & 15.3 & 21.9 & 0.0 \\
\hline Cervidellus & 1.7 & 0.0 & 1.3 & 4.5 & 0.0 & 25.9 \\
\hline Chiloplacus & 0.0 & 1.1 & 0.0 & 0.0 & 0.0 & 2.4 \\
\hline Eucephalobus & 3.4 & 0.0 & 0.0 & 0.0 & 6.3 & 4.7 \\
\hline Mesorhabditis & 13.0 & 11.8 & 11.1 & 12.6 & 0.0 & 12.9 \\
\hline Plectus & 0.0 & 0.0 & 3.7 & 0.0 & 1.0 & 3.5 \\
\hline Prismatolaimus & 0.9 & 2.4 & 4.9 & 0.0 & 0.0 & 0.0 \\
\hline Protorhabditis & 10.3 & 5.9 & 7.4 & 3.6 & 14.6 & 10.6 \\
\hline Wilsonema & 3.4 & 0.0 & 0.0 & 2.7 & 0.0 & 2.3 \\
\hline $\mathbf{F F}^{*}$ & 9.4 & 9.5 & 16.1 & 7.3 & 6.3 & 5.9 \\
\hline Aphelenchoides & 6.0 & 2.4 & 13.6 & 7.3 & 0.0 & 5.9 \\
\hline Paraphelenchus & 3.4 & 7.1 & 2.5 & 0.0 & 6.3 & 0.0 \\
\hline $\mathbf{P P}^{*}$ & 36.3 & 40.0 & 38.3 & 42.3 & 35.3 & 23.5 \\
\hline Bitylenchus & 0.0 & 7.0 & 2.5 & 1.8 & 0.0 & 0.0 \\
\hline Coslenchus & 1.7 & 0.0 & 12.3 & 0.0 & 0.0 & 2.4 \\
\hline Filenchus & 4.4 & 5.9 & 0.0 & 0.0 & 4.1 & 0.0 \\
\hline Helicotylenchus & 1.8 & 5.9 & 4.9 & 14.4 & 5.1 & 4.7 \\
\hline Hirschmanniella & 18.1 & 0.0 & 8.6 & 11.7 & 6.3 & 0.0 \\
\hline Macroposthonia & 2.6 & 1.2 & 0.0 & 0.0 & 4.2 & 4.7 \\
\hline Neothada & 0.0 & 0.0 & 0.0 & 3.6 & 3.1 & 1.1 \\
\hline Paratylenchus & 1.7 & 0.0 & 0.0 & 4.5 & 0.0 & 2.4 \\
\hline Pratylenchus & 0.0 & 20.0 & 0.0 & 0.0 & 0.0 & 3.5 \\
\hline Psilenchus & 0.0 & 0.0 & 0.0 & 2.7 & 12.5 & 4.7 \\
\hline Scutylenchus & 6.0 & 0.0 & 9.9 & 3.6 & 0.0 & 0.0 \\
\hline $\mathbf{O P}^{*}$ & 11.2 & 16.4 & 8.6 & 11.7 & 14.6 & 7.1 \\
\hline Aporcelaimellus & 0.0 & 0.0 & 0.0 & 0.0 & 0.0 & 4.7 \\
\hline Discolaimus & 0.0 & 0.0 & 6.2 & 0.0 & 0.0 & 2.4 \\
\hline Dorylaimoides & 5.2 & 4.7 & 0.0 & 6.3 & 7.3 & 0.0 \\
\hline Epidorylaimus & 4.3 & 2.4 & 0.0 & 5.4 & 0.0 & 0.0 \\
\hline Thonus & 0.0 & 2.4 & 2.5 & 0.0 & 4.2 & 0.0 \\
\hline Tylencholaimus & 1.7 & 7.0 & 0.0 & 0.0 & 3.1 & 0.0 \\
\hline
\end{tabular}


turity Index (MI) for free living nematodes and Plant Parasitic Index (PPI) for plant parasitic nematodes (Bongers, 1990); modified Maturity Index ( $\left.\sum M I\right)$, including plant parasitic nematodes (Bongers, 1990); Wasilewska index (WI) (Wasilewska, 1994); FF/BF ratio (Twinn, 1974); Shannon-Wiener Diversity Index ( $\mathrm{Hg})$ (Shannon \& Weaver, 1949); Pielou Evenness Index (J') (Pielou, 1975); Simpson Index $(\lambda)$ (Simpson, 1949); Species Richness Index (SR) (Yeates \& King, 1997); Trophic Diversity Index (TD) (Heip et al., 1988) and Nematode Channel Ratio (NCR) (Tomar et al., 2009).

Data were statistical analyzed by using Microsoft Excel 2000 and SPSS 11.0 software packages.

\section{Results, Discussion and Conclusions}

Five heavy metals were determined in the soil samples collected around the Gangue hill of Fushun West Open-pit mine and their contents are reported in Table 1. Among the soil samples the highest values of copper $(\mathrm{Cu})(84.22$ $\mathrm{mg} \cdot \mathrm{kg}^{-1}$ soil), lead $(\mathrm{Pb})\left(48.55 \mathrm{mg} \cdot \mathrm{kg}^{-1}\right.$ soil) and cadmium (Cd) $\left(2.75 \mathrm{mg} \cdot \mathrm{kg}^{-1}\right.$ soil) were found at site 3 ; the highest values of zinc $(\mathrm{Zn})\left(85.74 \mathrm{mg} \cdot \mathrm{kg}^{-1}\right.$ soil) and nickel (Ni) (156.34 mg kg ${ }^{-1}$ soil) were found at site 5 and 1 , respectively (Table 1).

The landscape of the Gangue hill is the result of gangue accumulation derived from anthropogenic activity, so the difference between its natural ingredients and those contained in natural mountains is significant. The relationship between pollution source and heavy metals concentrations in soil should be positively correlated, although the distance from pollution source and heavy metals concentrations in soil are negatively correlated according to the regularity of heavy metals migration in soil. However, with the exception of $\mathrm{Ni}$ soil concentration that was inversely proportional to the distance from Gangue hill, no significant correlation was observed among $\mathrm{Cu}, \mathrm{Pb}, \mathrm{Cd}$ and $\mathrm{Zn}$ soil concentrations and distance from Gangue hill (Table 1). Migration of heavy metals in soil is especially caused by the water in the soil environment. Sanches-Moreno and Navas (2007) published detailed results of a study on heavy metal polluted soils in southern Spain. This study focused on $\mathrm{Cu}, \mathrm{Ni}, \mathrm{Pb}$ and $\mathrm{Zn}$ effects of soils in an area polluted with toxic sludge of a pyrite mine. Total nematode abundance and divesity indices (WI, TD, $\lambda, \mathrm{Hg}, \mathrm{SR}$ ) and ecological indices (MI, PPI, $\sum$ MI) were significantly lower in polluted than in non polluted soils. Zhang et al. (2007b) have studied in northeast China the effect on nematode community of $\mathrm{Cu}$ and $\mathrm{Zn}$ pollution in corn field near a copper smelter. $\mathrm{Cu}$ and $\mathrm{Zn}$ soil contents showed significant decreases with increasing distance from the smelter. In our study no significant trend of changes was observed along the sampling direction with the increase of distance from Gangue hill. This phenomenon was probably due to the 5 $\mathrm{V}$-shape streams which derived from downside slope of Gangue hill and to the pattern of local irrigation. As consequence there was a disorder in the distribution of heavy metals concentrations in soil around Gangue hill.

According to the source of food, nematodes can be divided into four trophic groups: Bacterial feeders (BF); Fungal feeders (FF); Plant parasites (PP) and Omnivorous-predators (OP); they reflect the structure of trophic groups in soil food webs (Ferris et al., 2001). Nematological analysis showed that the most abundant trophic group was BF as observed in previous findings on other soil nematode communities although in different conditions (Liang et al., 2001; Renčo, 2003; 2004; Nahar et al., 2006; Lišková \& Renčo, 2007). Twenty-nine genera of nematodes were identified (Table 2). In particular, 10 genera were bacterivores, 2 genera were fungivores, 11 genera were plantparasites and 6 genera were omnivores-predators (Table 2). In the different sites, BF ranged between $34.1 \%$ and $63.5 \%$, FF from $5.9 \%$ and $16.1 \%$, PP from $23.5 \%$ and $42.3 \%$, and OP ranged between $7.1 \%$ and $16.4 \%$. The genera Crevidelus

Table 3. Diversity and ecological indices of nematodes in the different sampling sites around the Gangue hill of Fushun West Open-pit mine (Liaoning Province - China)

\begin{tabular}{ccccccc}
\hline Sites/Indices & 1 & 2 & 3 & 4 & 5 & 6 \\
\hline $\mathrm{S}$ & $20 * \mathrm{a}^{* *}$ & $16 \mathrm{~b}$ & $15 \mathrm{bc}$ & $16 \mathrm{~b}$ & $13 \mathrm{c}$ & $18 \mathrm{ab}$ \\
$\mathrm{WI}$ & $1.45 \mathrm{~b}$ & $1.09 \mathrm{bc}$ & $1.39 \mathrm{~b}$ & $1.11 \mathrm{~b}$ & $1.38 \mathrm{~b}$ & $2.95 \mathrm{a}$ \\
$\mathrm{FF} / \mathrm{BF}$ & $0.22 \mathrm{bc}$ & $0.28 \mathrm{~b}$ & $0.43 \mathrm{a}$ & $0.18 \mathrm{c}$ & $0.15 \mathrm{c}$ & $0.09 \mathrm{~d}$ \\
$\mathrm{TD}$ & $2.95 \mathrm{a}$ & $3.2 \mathrm{a}$ & $3.16 \mathrm{a}$ & $2.87 \mathrm{a}$ & $2.94 \mathrm{a}$ & $2.14 \mathrm{~b}$ \\
$\lambda$ & $0.09 \mathrm{a}$ & $0.1 \mathrm{a}$ & $0.09 \mathrm{a}$ & $0.09 \mathrm{a}$ & $0.11 \mathrm{a}$ & $0.12 \mathrm{a}$ \\
$\mathrm{Hg}$ & $2.7 \mathrm{a}$ & $2.5 \mathrm{a}$ & $2.54 \mathrm{a}$ & $2.54 \mathrm{a}$ & $2.37 \mathrm{a}$ & $2.52 \mathrm{a}$ \\
$\mathrm{MI}$ & $2.73 \mathrm{a}$ & $2.88 \mathrm{a}$ & $2.76 \mathrm{a}$ & $2.68 \mathrm{a}$ & $2.69 \mathrm{a}$ & $2.58 \mathrm{a}$ \\
$\mathrm{PPI}$ & $2.79 \mathrm{a}$ & $2.85 \mathrm{a}$ & $2.68 \mathrm{a}$ & $2.74 \mathrm{a}$ & $2.44 \mathrm{ab}$ & $2.55 \mathrm{a}$ \\
$\mathrm{KMI}$ & $7.6 \mathrm{~b}$ & $7.18 \mathrm{~b}$ & $7.13 \mathrm{~b}$ & $6.45 \mathrm{bc}$ & $7.26 \mathrm{~b}$ & $10.95 \mathrm{a}$ \\
$\mathrm{J}$ & $0.9 \mathrm{a}$ & $0.9 \mathrm{a}$ & $0.94 \mathrm{a}$ & $0.91 \mathrm{a}$ & $0.92 \mathrm{a}$ & $0.87 \mathrm{a}$ \\
$\mathrm{SR}$ & $8.2 \mathrm{a}$ & $3.38 \mathrm{~b}$ & $3.19 \mathrm{~b}$ & $3.18 \mathrm{~b}$ & $2.64 \mathrm{c}$ & $3.83 \mathrm{~b}$ \\
$\mathrm{NCR}$ & $0.82 \mathrm{ab}$ & $0.78 \mathrm{ab}$ & $0.7 \mathrm{~b}$ & $0.85 \mathrm{ab}$ & $0.87 \mathrm{ab}$ & $0.92 \mathrm{a}$ \\
\hline
\end{tabular}


(site 6), Acrobeloides, (sites 5 and 4) Mesorhabditis (sites 1 and 6) and Protorhabditis (site 5) were dominant in BF group. For PP group, Pratylenchus accounted $20.0 \%$ at site 2, Hirschmanniella $18.1 \%$ at site 1 and Helicotylenchus $14.4 \%$ at site 4 were the dominant genera. The genus Aphelenchoides (FF) compose $13.6 \%$ of total nematofauna at site 3 (Table 2). $\mathrm{BF}$ and $\mathrm{PP}$ had a higher absolute abundance at all sampling sites in comparison to FF and OP (Table 2). In particular, at site 1 , the nearest point to pollution source, these two trophic groups represented about $80 \%$ of the total number of nematodes indicating that the most tolerable species belong to these two trophic groups. These results are partialy in accordance with findings by Chen et al. (2008). These authors found that soil samples, collected along the Yellow River, in the Lanzhou area of China, in sites with a severe contamination by heavy metals, showed the lowest abundance of FF and OP and the highest proportion of BF. In contrast, in a site with a minor pollution by heavy metals the soil contained the highest abundance of PP. In our investigation most of the non-tolerable nematode genera were FF or OP and they could decrease their number or disappear if the environment conditions are significantly more pollutant (Table 2).

Mean WI values ranged between 1.09 and 2.95 and they are comparable to the mean values observed by Liang et al. (1999) for a potato field and by Pen-Mouratov et al. (2008) in a desert communities (Table 3 ).

The structure of the microflora community can be represented by FF/BF ratios. They reflect and indicate the status of the decomposition pathway in detrital food webs (Ruess, 2003). These values ranged between 0.09 and 0.43 and they were higher than that observed in a long term field experiment of organic manure soil treatments $(\mathrm{Hu} \& \mathrm{Qi}$, 2010), indicating a large bacterial population presence with a dominant bacterial decomposition pathway (Table 3 ).

Simpson index $(\lambda)$ was used to assess the dominance of all nematode genera in the samples and it weights common species. The observed $\lambda$ values $(0.09-0.12)$ were lower than that obtained by Pen-Mouratov et al. (2004) and Hu \& Qi (2010) (0.14 - 0.22) (Table 3) in uncontaminated areas and also than that recorded in similar polluted area in China (Tomar et al., 2009). The Shannon index (Hg) affords more weight to rare species, and a high value indicates greater diversity. The $\mathrm{Hg}$ values observed in this study ranged between 2.37 and 2.70 and they were higher than those observed by Bulluck et al. (2002) (0.55 - 1.47) in a soil in which tomato crop was cultivated and by Tomar et al. (2009) (1.65 - 2.06) close to polluted area of Highway (Table 3 ).

The maturity index (MI) is a valuable tool for evaluation of the impact of pollutants on nematodes and can reflect the degree of disturbance of the soil ecosystem. MI showed a decreasing trend with the increase of distance from Gangue hill (Table 3), because of the soil was impacted by anthropological factors and the land around Gangue hill was exploited and become farmland. The land far away from Gangue hill was exploited early, while the land close to it was exploited later. In this study MI values ranged from 2.58 to 2.88 and they were lower than that reported in Chinese paddy fields $(2.86-3.23)$ by Liu et al. (2008). The lower MI values observed suggested that abundant opportunist nematodes were present in the collected soil samples.

The plant parasitic indeces (PPI) ranged from 2.44 to 2.85 , and $\sum$ MI values ranged from 6.45 to 10.95 . PPI and MMI values were higher to that observed in the black soil region of Northeast China by Liang et al. (2002).

The calculated J' values $(0.87-0.94)$ were higher than that reported by Pen-Mouratov et al. (2008) and $\mathrm{Hu} \& \mathrm{Qi}$ (2010) $(0.77-0.84)$. The species richness (SR) values $(2.64-8.20)$ were in accordance with that reported by Yeates \& King (1997) (Table 3).

Table 4. Correlation coefficients between community indices of nematodes and heavy metal contents in the sampling sites around the Gangue hill of Fushun West Open-pit mine (Liaoning Province - China)

\begin{tabular}{cccccc}
\hline $\begin{array}{c}\text { Heavy metals } \\
\text { /Indices }\end{array}$ & $\mathrm{Cu}$ & $\mathrm{Zn}$ & $\mathrm{Pb}$ & $\mathrm{Cd}$ & $\mathrm{Ni}$ \\
\hline $\mathrm{TNEM}$ & $0.831^{*}$ & 0.185 & 0.647 & 0.426 & 0.08 \\
$\mathrm{~S}$ & 0.431 & -0.408 & 0.209 & 0.357 & $.629^{* *}$ \\
$\mathrm{WI}$ & -0.02 & 0.248 & -0.188 & -0.159 & -0.152 \\
$\mathrm{FF} / \mathrm{BF}$ & $.603^{* *}$ & 0.011 & $.597^{* *}$ & $.689^{* *}$ & 0.123 \\
$\mathrm{TD}$ & 0.158 & -0.043 & 0.383 & 0.443 & 0.146 \\
$\lambda$ & -0.303 & 0.328 & -0.226 & -0.186 & -0.238 \\
$\mathrm{Hg}$ & 0.374 & -0.024 & 0.29 & 0.407 & $.517^{*}$ \\
$\mathrm{MI}$ & 0.149 & 0.098 & 0.236 & $.475^{*}$ & 0.17 \\
$\mathrm{PPI}$ & 0.409 & -0.376 & 0.264 & $.623^{* *}$ & 0.35 \\
$\sum \mathrm{MI}$ & -0.09 & 0.195 & -0.135 & -0.085 & -0.093 \\
$\mathrm{~J}$ & -0.062 & 0.148 & 0.245 & 0.073 & 0.134 \\
$\mathrm{SR}$ & 0.404 & -0.353 & 0.438 & 0.318 & $.959^{* *}$ \\
$\mathrm{NCR}$ & -0.337 & 0.293 & -0.404 & -0.381 & -0.1 \\
\hline *significant at $\mathrm{P}=0.05 ; * *$ significant at $\mathrm{P}=0.01$ & & & &
\end{tabular}


If the correlation between community indices and heavy metal contents was concerned we can observed that: TNEM was only positively correlated with $\mathrm{Cu}$ soil content $(\mathrm{P}=0.05)$; the values of $\mathrm{S}, \mathrm{Hg}$ and $\mathrm{SR}$ were only positively correlated with $\mathrm{Ni}$ soil content $(\mathrm{P}<0.05)$; $\mathrm{PPI}$ and $\mathrm{MI}$ were only positively correlated with $\mathrm{Cd}$ soil content $(\mathrm{P}<0.05)$; FF/BF was positively correlated with $\mathrm{Cu}, \mathrm{Pb}$ and $\mathrm{Cd}$ at a higher statistical probability $(\mathrm{P}=0.01)$ (Table 4$)$.

In conclusion, on the base of results of this investigation and of that of previous studies it is difficult to make genaralizations about the effect of heavy metal contanimations on soil nematode comminities. Results of soil nematological analysis are largely influenced by the ecosystem type, $\mathrm{pH}$ soil, vegetation and many other factors. However, in general, heavy metals had an adverse effect on the changes of nematode community structure (TNEM, richness and maturity indices) to which they are correlated. In every case, nematode communities remain the most important and significant biological indicators of soil pollution.

\section{Reference}

Barker, K. R., CArter, C. C., SAsser, J. N. (1985): An Advanced Treatise on Meloidogyne, Methodology, Vol. 2. North Carolina State University Graphics, Raleigh, NC, Pp. 223

BONGERS, T. (1990): The maturity index: an ecological measure of environmental disturbance based on nematode species composition. Oecologia, 83: 14 - 19. DOI: 10.100 7/BF00324627

Bulluck, L. R., BARKer, K. R., Ristaino, J. B. (2002): Influences of organic and synthetic soil fertility amendments on nematode trophic groups and community dynamics under tomatoes. Appl. Soil Ecol., 21: 233 - 250. DOI: 10.1016/S0929-1393(02)00089-6

ČEREVKOVÁ, A., RENČO, M. (2009): Soil nematode community changes associated with windfall and wildfire in forest soil at the High Tatras National Park, Slovak Republic. Helminthologia, 46: 123 - 130. DOI: 10.2478/s116 87-009-0024-9

Chen, G., QIN, J., ShI, D., Zhang, Y., Ji, W. (2008): Diversity of Soil Nematodes in Areas Polluetd with Heavy Metals and Polycyclic Aromatic Hydrocarbons (PAHs) in Lanzhou, China. Environ. Manag., 44(1): 163 - 172. DOI: 10.1007/s00267-008-9268-2

Ferris, H., Bongers T., De Goede, R. G. M. (2001): A framework for soil food web diagnostics: extension of the nematode faunal analysis concept. Appl. Soil Ecol., 18: 13 - 29. DOI: 10.1016/S0929-1393(01)00152-4

Ferris, H., Venette, R. C., Scow, K. M. (2004): Soil management to enhance bacterivore and fungivore nematode populations and their nitrogen mineralization function. Appl. Soil Ecol., 25: 19 - 35. DOI: 10.1016/j.apsoil. 2003.07.001

FRECKMAN, D. W. (1988): Bacterivorous nematodes and organic matter decomposition. Agr. Ecosyst. Environ., 24: 195 - 217. DOI: 10.1016/0167-8809(88) 90066-7.

Freckman, D. W., EtTemA, C. H. (1993): Assessing nematode communities in Agri-ecosystems of varying human intervention. Agriculture. Ecosyst. and Environ., 45: 239 - 261. DOI: 10.1016/0167-8809(93)90074-Y

FRECKMAN, D. W., VirginiA, R. A. (1997): Low-diversity Antarctic soil nematode communities: distribution and response to disturbance. Ecology, 78: 363 - 369. DOI: 10.1016/S1164-5563(02)01155-X

Fu, S. L., Coleman, D. C., Hendrix, P. F., Crossley Jr. D. A. (2000): Responses of trophic groups of soil nematodes to residue application under conventional tillage and no-till regimes. Soil Biol. Biochem., 32: 1731 - 1741. DOI: 10.1016/S0038-0717(00)00091-2

HÁNĚL, L. (2003): Recovery of soil nematode populations from cropping stress by natural secondary succession to meadow land. Appl. Soil Ecol., 22: 255 - 270. DOI: 10.10 16/S0929-1393(02)00152-X

Heip, C., Herman, P. M. J., Soetaert, K. (1988): Data processing evaluation and analysis. In HigGINS, R.P. \& THIEL, H. (Eds.). Introduction to the study of mesofauna, Smithsonian Institution Press, Washington, D.C.

HU, F., LIN, M. S., WU, S. M. (1993): Characteristics of nematode population in low hill red soil ecosystems in central Jiangxi Province, subtropical China (In Chinese). In: Wang, M. Z., ZHANG, T. L., HE, Y. Q. (Eds) Res. on Red Soil Ecosyst. Beijing, China: Agricultural Science and Technology Press, pp. $177-182$

HU, F., LI, H. X., XIE, L. Q. (1999): Interactions of bacterivorous nematode and bacteria and their effects on mineralization-immobilization of nitrogen and phosphorous (In Chinese). Acta Ecol. Sinica, 19(6): 914 - 920

HU, C., QI, C. (2010): Abundance and diversity of soil nematodes as influenced by different types of organic manure. Helminthologia, 47(1): 58 - 66. DOI: 10.2478/s11 687-010-009-8

Ingham, R. E., Trofymow, J. A., Ingham, E. R., COLEMAN, D. C. (1985): Interactions of bacteria, fungi, and their nematode grazers effects of nutrient cycling and plant growth. Ecol. Monographs, 55: 119 - 140. DOI: $10.2307 / 19422528$

LI, H. X., LIU, M. Q., HU, F. (2002): Nematode abundance under different vegetations restored on degraded Red Soil (In Chinese). Acta Ecol. Sinica, 22(11): 1882 - 1889

LiAnG, W. J., LAVIAN, I., SteinBerger, Y. (1999): Dynamics of nematode community composition in a potato field. Pedobiologia, 43: 459 - 469

Liang, W. J., Lavian, I., Pen-Mouratov, S. (2001): Diversity and dynamics of soil free-living nematode populations in a Mediterranean agroecosystem. Pedosphere, 33: $208-213$

LiAng, W. J., ChEN, L. J., LI, Q., WANG, P., DUAN, Y. X. (2002): Responses of nematode communities to inorganic fertilizer disturbance in a farmland ecosystem. Pedosphere, 12(3): $193-200$

LIANG, W. J., LI, Q., JIANG, Y. (2005): Nematode faunal analysis in an aquic brown soil fertilized with slow-release urea, Northeast China . Appl. Soil Ecol., 29: 185 - 192. DOI: 10.1016/j.apsoil.2004.10.004

LIŠKOVÁ, M., RENČO, M. (2007): Communities of free 
living and plant parasitic nematodes in hop gardens in Slovakia. Helminthologia, 44: 80 - 86. DOI: 10.2478/s116 87-007-0008-6

LIU, M. Q., ChEN, X. Y., QIN, J. T., WANG, D., GRIFFITHS, B., HU, F. (2008): A sequential extraction procedure reveals that water management affects soil nematode communities in paddy fields. Appl. Soil Ecol., 40: 250 - 259. DOI: 10.1016/j.apsoil.2008.05.001

Nahar, M. S., Grewal, P. S., Miller, S. A., Stinner, D., Stinner, B. R., Kleinhenz, M. D., Wszelaki, A., DoOHAN, D. (2006): Differential effects of raw and composted manure on nematode community, and its indicative value for soil microbial, physical and chemical properties. Appl. Soil Ecol., 34: 140 - 151. DOI: 10.1016/j.apsoil. 2006.03.011

Panesar, T. S., Marshall, V. G., Barclay, H. J. (2001): Abundance and diversity of soil nematode in chronosequences of coastal Douglas-fir forests on Vancouver island. British Columbia. Pedobiologia, 45: 193 212. DOI: $10.1078 / 0031-4056-00080$

Pate, E., Ndiaye-Faye, N., Thioulouse, J., Villenave, C., Bongers, T., Cadet, P., Debouzie, D. (2000): Successional trends in the characteristics of soil nematode communities in cropped and fallow lands in Senegal (sonkorong). Appl. Soil Ecol., 14: 5 - 15. DOI: 10.1016/09 29-1393(99)00051-7.

Pen-Mouratov, S., Rakhimbaev, M., BARness, G., SteINBERGER, Y. (2004): Spatial and temporal dynamics of nematode populations under Zygophyllum dumosum in arid environments. Eur. J. Soil Biol., 40: 31 - 46. DOI: 10.1016/j.ejsobi.2004.01.002

Pen-Mouratov, S., Barness, G., Steinberger, Y. (2008): Effect of desert plant ecophysiological adaptation on soil nematode communities. Eur. J. Soil Biol., 44: 298 308. DOI: 10.1016/j.ejsobi.2008.03.005

PIELOU, E. C. (1975): Ecological diversity. New York: John Wiley, pp. 165

Powers, L. E., Freckman, D. W., Virginia, R. A. (1995): Spatial distribution of nematodes in polar desert soils of Antarctica. Polar Biol., 15: 325 - 333. DOI: 10.1007/BF0 0238482.

RENČO, M. (2003): The communities of nematodes in agroecosystems of sugar beet, cereals and lucerne in Eastern Slovakia. Helminthologia, 40(1): 55 - 58

RENČO, M. (2004): Communities of nematodes in cereal fields following sugar beet. Helminthologia, 41(2): 109- 112 RENČO, M., LiŠKOVÁ, M., ČEREVKOVÁ, A. (2010): Seasonal fluctuations of the nematode communities in a hop garden soil. Helminthologia, 47(2): 115 - 122. DOI: 10.2478/s11687-010-0018-7

Ritz, K., TrudgiLl, D. L. (1999): Utility of nematode community analysis as an integrated measure of functional state of soils: perpectives and challenges. Plant Soil, 212: 1 - 11. DOI: $10.1023 / \mathrm{A}: 1004673027625$.

RUESS, L. (2003): Nematode soil faunal analysis of decomposition pathways in different ecosystems. Nematology, 5, 179 - 181. DOI: 10.1163/156854103767139662

SANCHEZ-MorenO, S., NAVAS, A. (2007): Nematode dive- sity and food web condition in heavy metal polluted soils in a river bacin in southern Spain. Eur. J. Soil Biol., 43: 166 - 179. DOI: 10.1016/j.ejsobi.2007.01002

ShanNON, C. E., WeAver, W. (1949): The Mathematical Theory of Communication. Urbana, IL: University of Illinois Press.

SIMPSON, E. H. (1949): Measurement of diversity. Nature, 163: 668

Sohlenius, B., Bostrom, S., SAndor, A. (1987): Longterm dynamics of nematode communities in arable soil under four cropping systems. J. Appl. Ecol., 24: 131 - 144. TOMAR, V. V. S., ZHANG, X. K., LI, Q., JiANG, Y., LIANG, W. J. (2009): Distribution of soil nematode along a section of Shen-Ha Highway. Helminthologia, 46(4): 241 - 246. DOI: $10.2478 / \mathrm{s} 11687-009-0044-5$

Twinn, D. C. (1974): Nematodes. In: Dickinson, C. H., Pugh, G. J. F. (Eds) 'Biology of Plant Litter Decomposition'. pp. 421 - 465. (Academic Press: London)

WANG, Z. Z., ZhANG, Y. M., Wu, H. S. (1992): Study towards the eco-geographic community of Mountain soil Nematoda in the middle of Hunan (In Chinese). J. Natural Scie. Hunan Normal University, 15 (3): $72-78$

Wardle, D. A., Yeates, G. W., Watson, R. N., NiCHOLSON, K.S. (1995): The detritus food-web and the diversity of soil fauna as indicators of disturbance regimes in agro-ecosytems. Plant Soil, 170: 35 - 43. DOI: 10.1007/ BF02183053

WASILEWSKA, L. (1994): The effect of age of meadows on succession and diversity in soil nematode communities. Pedobiologia, 38: 1 - 11

WASILEWSKA, L. (1997): Soil invertebrates as bioindicators, with special reference to soil-inhabiting nematodes. Russ. J. Nematol., 5: $113-126$

WASILEWSKA, L. (2006): Changes in the structure of the soil nematode community over long-term secondary grassland succession in drained fen peat. Appl. Soil Ecol., 32: 165 - 179. DOI: 10.1016/j.apsoil.200507.003.

Wu, J. H., FU, C. C., LU, F., CHEN, J. (2005): Changes in free-living nematode community structure in relation to progressive land reclamation at an intertidal marsh. Appl. Soil Ecol., 29: 47 - 58. DOI: 10.1016/j.apsoil.2004.09.003. YARDiM, E. N., EDWARDS, C. A. (1998): The effect of chemical pest, disease and weed management practices on the trophic structure of nematode populations in tomato agroecosystems. Appl. Soil Ecol., 7: 137 - 147. DOI: 10.10 16/S0929-1393(97) 00036-X.

Yeates, G. W., Bongers, T., De Goede, R. G. M., FreckMan, D.W., Giorgieva, S.S. (1993): Feeding habits in nematode families and genera - an outline for soil ecologists. J. Nematol., 25: $315-331$

YeATES, G. W., KING, K. L. (1997): Soil nematodes as indicators of the effect of management on grasslands in the New England Tablelands (NSW): Comparison of native and improved grasslands. Pedobiologia, 41, 526 - 536

Yeates, G. W., Newton, P. C. D., Ross, D. J. (1999a): Response of soil nematode fauna to naturally elevated $\mathrm{CO}_{2}$ levels influenced by soil pattern. Nematology, 1: $285-$ 293. DOI: $10.1163 / 156854199508289$ 
Yeates, G. W., Wardle, D. A., Watson, R. N. (1999b): Responses of soil nematode populations. Community structure, diversity and temporal variability to agricultural intensification over a seven-year period. Soil Biol. Biochem., 31: 1721 - 1733. DOI: 10.1016/S0038-0717(99) 00091-7

ZhANG, X. K., LiAnG, W. J., JiAng, D. M., LiU, Z. M., JIANG, S. W. (2007a): Soil nematode community structure in a Chinese sand dune system. Helminthologia, 44(4): 204 - 209. DOI: 10.2478/s11687-007-0032-6

RECEIVED MARCH 23, 2010
ZHANG, W. D., WANG, X. F., LI, Q., JiAnG, J., LIANG, W. J. (2007b): Soil nematode responses to heavy metal stress. Helminthologia, 44: 87-91. DOI: 10.2478/s11687-0070009-5

ZOLDA, P., HÁNĚL, L. (2007): Soil nematodes inhabiting an original dry meadow and an abandoned vineyard in the National Park Seewinkel, Eastern Austria. Helminthologia, 44(3): 112 - 117. DOI: 10.2478/s11687-007-0016-6 